Savunma Bilimleri Dergisi

The Journal of Defense Sciences

Kasim / Nov 2019, Cilt/Volume 18/2, Say1/Issue 36.

ISSN (Bas111) : 1303-6831 ISSN (Online): 2148-1776

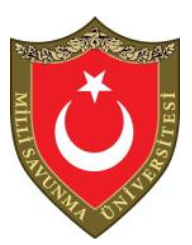

\title{
Silahlı İnsansız Hava Araçlarının Uluslararası Alanda ve İç Güvenlikte Sevk ve İdaresine İlişkin Hukuki Saptamalar
}

\author{
Tarık $\mathrm{AK}^{*}$ ve Tekin AVANER ${ }^{* *}$ \\ $\ddot{O} z$
}

Günümüzde Silahlı İnsansız Hava Araçları (SïHA)'nın zaman ve mekân üstünlüğü, asimetrik etkisi, ekonomikliği, kullanıcısının çatışma bölgesinden uzaklı̆̆ veya ölme riski taşımaması ülkeler tarafindan önemli bir avantaj olarak görülmektedir. Ayrıca, SIHA operasyonlarının cana ve mala ilişkin herhangi bir ilave maliyet yaratmaması bu ülkelerin kamuoyları nezdinde yürütülen politikalara tolerans ve destek sağlamaktadır. Bu silahlı araçları diğerlerinden ayıran temel özellikler için ise şunlar söylenebilir: (l) Karar vericilerin, SIHA atıslarının nerede ve nasıl yapılacağına ilişkin süreci takip edebilmeleri ve katkı sağlayabilme imkânı, (ul) İnsanlı uçağa göre hedef üzerinde daha uzun kalma avantajı sayesinde sivil kişilere olan zayiatı en aza indirebilme imkânı. Bu makale, SiHA 'ların önümüzdeki yıllarda daha da fazla kullanılması durumuyla karşılaşılacağından, hukuki bağlamda tespitler yaparak bugünü anlamayı amaçlamaktadır. Bu sayede, SiHA'lara ilişkin hem ulusal güvenliğe hem de iç güvenliğine yönelik yeni yaklaşımların ortaya konulmasına fayda sağlanabileceği değerlendirilmektedir. Bu araçların uluslararası ve ulusal alanda kullanımına ilişkin öngörülerde bulunmak, modern toplumun hayatına giren bu teknolojilerin etkilerine hazırlıklı olmaya katk sağlayacaktır.

Anahtar Kelimeler: $\dot{I}_{c ̧}$ Güvenlik, Silahlı Insansız Hava Aracı, Uluslararası İnsani Hukuk, Sevk ve İdare.

\footnotetext{
* Dr., Jandarma ve Sahil Güvenlik Akademisi, Güvenlik Bilimleri Enstitüsü, tarikak@jandarma.gov.tr, ORCID No: 0000-0001-8452-1601

${ }^{* *}$ Dr.Öğr. Üyesi, Jandarma ve Sahil Güvenlik Akademisi, Güvenlik Bilimleri Enstitüsü, tekinavaner@jandarma.gov.tr, ORCID No:0000-0003-4014-0131

Geliş Tarihi/Received : 08.02.2019

Kabul Tarihi/Accepted : 09.09.2019

Araştırma Makalesi/Research Article
} 


\title{
Legal Remarks on Command and Control of Armed Unmanned Aerial Vehicles in International Area and Internal Security
}

\begin{abstract}
Today, it is seen as a significant advantage by countries that armed unmanned aerial vehicles (AUAV) have made considerable contributions to terrestrial and air superiority in combat, have asymmetrical impact, and are time-saving and costeffective. In addition to all these, the fact that AUAVs are remotely controlled by operators away from the operation zone and therefore the absence of lifethreatening risk to operators makes AUAVs practical and advantageous. Furthermore, the fact that the AUAV operations do not create any additional costs in terms of lives and properties provides tolerance and support for public policies of these countries. The basic features that distinguish these armed vehicles from others are as follows: (i) The ability of decision-makers to follow and contribute to the process of where and how the AUAV firing will take place. (ii) Possibility of minimizing the damage to civilians due to the advantage of staying airborne on the target longer compared to manned aircraft. This article aims to understand today by making observations in the legal context, as it will be seen in the coming years that AUAVs will be used more and more. In this way, it is considered that new approaches to both national security and internal security can be benefited. Foreseeing the international and national use of these vehicles will contribute to the preparedness for the effects of these technologies for life in modern society.
\end{abstract}

Keywords: Internal Security, Armed Unmanned Aerial Vehicle, International Humanitarian Law, Command and Control.

\section{Giriş}

Silahlı İnsansız Hava Araçları (SİHA)'nın kullanımının üzerinden on beş yıldan fazla zaman geçti. İlk defa 2001 yılında ABD'nin İHA'ları silahlandırmasıyla başlayan süreç, İsrail'den Çin'e AB ülkelerinden Hindistan'a kadar dünya ve bölge siyasetinde aktif rol almak isteyen ülkelerce vazgeçilmez bir konuma getirildi. Geçen yıllar içerisinde araçlar; istenen performans ve işlevlerine bağlı olarak farklı boy ve ebatta tasarlandı, taşıdıkları silah ve mühimmatın 
Silahlı İnsansız Hava Araçlarının Uluslararası Alanda ve İç Güvenlikte

Sevk ve İdaresine İlişkin Hukuki Saptamalar

çeşitliliğine göre araç ailesi geniş̧letildi (US DoD, 2013: 4-6; UK MoD, 2017: 18). Günümüzde SİHA'ların zaman ve mekâna sahip olma avantajı, asimetrik etkisi, ekonomikliği, kullanıcısının çatışma bölgesinden uzaklığı ile öldürülme riski taşımaması gibi hususlar, ordular açısından temel üstünlük kazanımları olarak görülmektedir (UN, 2013; Ak, 2017: 7). Hatta SïHA'ların çatışma alanlarında kullanım kolaylığı, bu araçların dünyada mevcut çatışmaları daha da arttırdığı yönünde eleştirilere de sebep olmuştur (Woodhams \& Borrie, 2018: 2). Diğer taraftan, devletlerin yoğun talep gösterdiği bu araçlara terör ve suç örgütleri de ilgi göstermişlerdir. Terör ve suç örgütlerinin daha çok; (1) Arazi açısından ulaşılması zor alanlara saldırabilmek (11) Verebilecekleri zayiatlarda ölüm oranını arttırmak (111) Saldırının uzaktan yapılabilmesi sayesinde gizlenebilmek (1v) Makul fiyatlı bir teknolojiye ulaşabilmek (v) Alçaktan uçuş gerçekleştirerek ülkelerin hava savunma sistemlerinden kurtulabilmek (v1) Toplumda daha kolay korku ve panik yaratabilmek adına bu araçlara yöneldiği görülmektedir (Sathyamoorthy, 2015).

Günümüzde; ABD, Birleşik Krallık, Rusya, Çin gibi ülkelerin İHA ve SİHA'larının kullanım usullerinde uluslararası hukukun evrensel normlarını aşındıran, devletlerin egemenlik ve eşitlik ilkelerini olumsuz yönde etkileyen fiili durumlar yarattıkları söylenebilir. Örneğin ABD'nin SİHA ve İHA'ları dünyada Afganistan gibi ülkelerde bu ülkenin izni ile hava operasyonları gerçekleştirebildiği gibi, kendisine karşı yanıt verme yeteneğinin sınırlı olduğu ülkelerde izin alınmadan hava operasyonları da yapabildiği görülmektedir. $\mathrm{Bu}$ bağlamda ABD'nin fiili durum yarattığ hareketlere şu şekilde örnekler sıralanabilir. (1) ABD'nin, ülkelerin kendi hava sahası içerisinde operasyon izni vermeyen ve olması durumunda karşı taarruzla cevap verme kabiliyetine sahip olan ülkelerin hava sahasında SİHA operasyonları gerçekleştirebilmesi. Buna örnek olarak Pakistan verilebilir. ABD'nin Pakistan'da sivillerin ölümüne neden olan SİHA operasyonlarına Pakistan tarafından egemenlik haklarının ihlal edildiği yönünde karşı çıkılmaktadır. Pakistan, ABD'nin ülkesinden havalanan SİHA'ların Afganistan dışında Pakistan'da kullanılması durumunda karşılık verileceğini beyan etmiş, ancak ABD Afganistan'da kendi üslerine yönelik saldırılar yapmak amacıyla teröristlerin Pakistan sınır bölgelerinde örgütlendiklerini iddia ederek operasyonlarına devam etmiştir. (11) Diğer bir hususta, ABD'nin müttefik ülkelerinin yardım talebi üzerinden gerçekleştirdiği hava operasyonlarıdır. Buna 
örnek olarak Mali'de gerçekleştirilen hava operasyonları vurgulanabilir. Mali, ülkesinde terörle mücadele kapsamında Fransa'yı işbirliği için davet etmiş, Fransa ise bu mücadelede ABD'den yardım talep etmiştir. (111) Bir başka İHA ve SİHA uçuşlarına örnek ise ABD'nin Çin ile karşıllklı rekabeti nedeniyle Güney Çin denizinde Çin sınırına yakın uluslararası hava sahasında uçuşlar gerçekleştirmesidir. Burada ABD ile Çin arasında hasmane hareketler benimsenmesine rağmen eylemsel bir saldırı gerçekleştirilmemekte, gözetleme ve keşif devriyeleri icra edilmektedir. Özellikle son yıllarda Çin'in Güney Çin Denizi'nde yer alan adalar ve doğal kaynaklar üzerindeki egemenlik ve hak iddialarında bulunması iki ülke arasında rekabeti tırmandırmıştır (Schaus \& Johnson, 2018: 3-9).

Söz konusu örneklerde de vurgulandığı üzere SïHA'lara ilginin her geçen gün arttığı bu günlerde bu çalışma ile araçların kullanımlarının hâlihazırda nasıl bir seyir izlendiğinin anlaşılması ve kullanımı nedeniyle ortaya çıkan etik ve hukuki beklentilerin saptanması hedeflenmiştir. Bu maksatla çalışma içerisinde, ilk olarak SİHA'ların uluslararası alanda kullanım usulleri incelenecek ve hukuki bağlamda tartışılacak, müteakiben de iç güvenlikte görevlendirilmelerine ilişkin değerlendirmeler yapılacaktır.

SİHA'lar insansız savaş araçları ailesi içinde geçen, uzaktan komuta ile kontrol edilebilen, silah ve mühimmatları sayesinde öldürücü olan mürettebatsız araçlardır. İnsansız bir uçak, bu uçağı kontrol etmek için gerekli ekipman, altyapı ve personeli içeren bileşenlerden oluşan araç ve sistemlerinin ortak adıdır. Bu araçlar; (1) Operatör veya diğer araç ve sistemler ile irtibatı sağlayan iletişim sistemleri, (11) Araçlarda kullanılan yanmalı motor, gaz türbini, güneş pili ve benzeri motor veya itiş gücü teknolojisi, (111) Taşıdığı yük kapasitesi, ebat ve ölçüsü, (1v) Taşıdığı silah tipi ve sayısına göre farklılaşmaktadır ${ }^{1}$ (Quintana, 2008: 5-6; Ak, 2017: 21-29). SïHA'ları kullanan ülkeler açısından bu araçlar üç hususta avantaj sağlayabilir. Bunlar; kullanıcı ölümlerini azaltması, ekonomikliği ve toplumsal itibar kazandırmasıdır. SiHA pilotlarının vurulma riskinin olmaması kullanıcı açısından insan zayiatını ortadan kaldırmıştır. Üstelik tedarik ve kullanım maliyeti insanlı araçlara göre çok daha uygundur. Ayrıca SIHHA operasyonlarının can ve mal açısından herhangi bir ilave maliyet yaratmaması bu ülkelerin kamuoyları nezdinde siyasilerin yürüttükleri politikalara müsamaha ve destek sağlanmasına imkân vermektedir (Pejic, 2015: 3; Schaus \& Johnson, 2018: 3). 
Silahlı İnsansız Hava Araçlarının Uluslararası Alanda ve İç Güvenlikte

Sevk ve İdaresine İlişkin Hukuki Saptamalar

\section{SİHA ile Diğer Silah ve Sistemler}

SİHA'lar yasaklanmış bir silah veya sistem değildir. Ancak, uluslararası anlaşmalarda diğer silah ve sistemlere uygulanan sınırlamalar SİHA'lar için de geçerlidir. Nitekim, SİHA'lar, kimyasal ve biyolojik başlıklı veya misket bombaları içeren mühimmatların yüklenmesi ile mühimmatın ağırlığı ve menzili gibi konularda 1983 y1lı Belirli Konvansiyonel Silahlar Sözleşmesi ve 1987 yılı Füze Teknolojisi Kontrol Rejimine tabidir (Pejic, 2015: 4; Davis vd., 2014: 23). SïHA'lar, insanlı ve insansız araçlar ile aynı yasa ve politikaları takip ederken ilk yıllarda belirli bir hedefe yüzlerce kilometre öteden füze atan sistemlere de benzetilmiştir (Pejic, 2015: 3). SİHA'ları diğer silah ve sistemlerden ayıran özellikler için şunlar söylenebilir: (1) Komutanların ve siyasi karar vericilerin, SïHA saldırılarının nerede ve nasıl olacağına ilişkin düşünce veya risk hesaplamalarını kullanıcılar ile birlikte yapabilmesi ${ }^{2}$ (Schaus \& Johnson, 2018: 5). (11) İnsanlı uçağa göre hedef üzerinde daha uzun kalma avantajı, hedefi tanımlama sürecine daha fazla zaman ayırabilmesi ve bu sayede sivil insan zayiatının en aza indirilebilmesidir. Sivil kayıpları en aza indirebilme avantajı, diğer silah ve sistemlerle kıyaslandığında insanlı uçaklarda daha zor iken uzun menzilli füzelerde uygulanabilmesi gerçekçi değildir.

SİHA'ların dünyada hasım ülkeler arasında kullanılırken düşürülme sıklıklarının artması, bu araçların insanlı uçaklar ile aynı kategoride değerlendirilebilir olup olmaması hususunda tereddüt oluşturmuştur. Örneğin ABD, İnsansız Hava Araçları (İHA)'nı askeri uçak olarak kabul ederek, İHA'larının bir saldırıya maruz kalması durumunda insanlı bir uçağa yapılan saldırıya benzer bir cevabın verilmesini öngörmüştür. İnsanlı bir uçağa saldırı, kışkırtıcı bir hareket veya muhtemel bir çatışma girişimi olarak değerlendirilebilir iken bir İHA'nın düşürülmesinin insanlı bir uçağa saldırmak kadar kışkırtıcı olup olmadığı yoruma açıktır. Nitekim son yıllarda, politikacıların ve komutanların hem İHA'yı kaybetmenin getirdiği düşük risk düzeyinden faydalanarak hem de yurt içinde kamuoyu ve yurt dışında toplumsal kesimlerin baskısından kurtulmak için yüksek riskli görevlere insanlı uçak yerine sık sık İHA'ları tercih ettikleri de bir gerçektir. Şimdilik, ABD'nin yaklaşımı hariç tutulursa İHA'ya yönelik saldırıların nasıl algılandığı konusunda belirsizlik hâkimdir. Bu nedenle; (1) Bir İHA'ya saldırı 
yapıldığında, insanlı bir sisteme yapılan saldırı ile aynı seviyede mi karşılık verilmelidir? (11) İHA'lar insanlı bir uçaktan düşük riskler taşıdığından saldırıya orantılı alternatifler mi aranmalıdır? (111) Hasımdan gelen İHA saldırılarına hiç bir yanıt verilmez ise hasmın daha sonraki insansız araçlara yönelik muhtemel saldırıların düzeyi ve miktarı artar mı? Soruları ortadadır ancak yakın zamanda karşılık bulacakları açıktır (Schaus \& Johnson, 2018: 5).

\section{SïHA'ların Uluslararası Alanda Kullanımına İlişkin Hukuki Tartışmalar}

SİHA'ların sağladığı politik ve askeri avantajlar dikkate alındığında, araçların günümüzde daha da rağbet göreceği kuşku götürmez. Ancak bu araçlara ilişkin etik tartışma ve hukuki saptamaların gerçekleştirilmesi, kullanımına oranla daha yavaş bir seyir izlemekte, hatta gereken ilgiyi görmemektedir. SiHA'ların kullanımında etik tartışma ve yasal çerçeve gereksinimleri için ilginin azlığına yönelik şunlar söylenebilir (Holloway vd., 2018: 42). İlki; ABD ve Çin gibi uluslararası ortamda güçlü ve baskın ülkelerin hâlihazırda bu araçları aktif bir şekilde kullanmasına rağmen etik ve yasal tespitler konusundaki tartışmalara çekimser duruşlarıdır. İkincisi; araçların kullanımına ilişkin politik hedeflerin kazanımları ile askeri açıdan işlevsel çeşitliliğinin hâla yaşanmaya devam ediyor olmasıdır. Nitekim ABD'nin kendi terörle mücadele siyaseti kapsamında meşru müdafaa gayesiyle dünyada savaş ve çatışma bölgeleri haricinde de SiHH'ları kullandığı ülkelere rastlanmaktadır ya da ülkelerinde teröre maruz kalan ülkeler iç güvenliğinin sağlanmasında bu araçlara başvurabilmektedir. Üçüncüsü ise; SïHA'ların önümüzdeki on yıllarda yapay zekâ teknolojilerinde gelişmelerle birlikte kazanacağı tam otomasyon yeteneğinin etik ve hukuki tartışmaları kökten değiştirebileceğine duyulan ortak inançtır.

Günümüzde SïHA'ların politik ve askeri gerekçelerle kullanımının uluslararası hukuk açısından değerlendirmeye muhtaç olduğu açıktır. Özellikle SİHA kullanımının devletlerin egemenlik ve eşitliği bağlamında, kuvvet kullanma, insan hakları ve insancıl hukukun işlerliği açısından zorlayan bir etki yaptığı söylenebilir. Uluslararası alanda ülkeler tarafindan kabul gören devletlerin egemenliği ve eşitliği ilkesi, genel ilke olarak İkinci Dünya Savaşı sonrası BM’nin de öncülüğünde her devlete, diğer devletlerin tam saygılı olmasını ve sistemin hukuk kurallarına karşı eşit koruma sahibi olmasını sağlayacak bir yaklaşım olarak 
Silahlı İnsansız Hava Araçlarının Uluslararası Alanda ve İç Güvenlikte

Sevk ve İdaresine İlişkin Hukuki Saptamalar

kabul edilmiştir. Bu sayede her zaman bir ihtimal dâhilinde olan ve uluslararası sistemi tehdit eden savaşlar, bir devlete karşı kuvvet kullanma hali olarak yasaklanmış ya da belirli şartlara bağlanmıştır. BM üyesi bir devletin, herhangi bir devletin siyasi bağımsızlığına ve ülke bütünlüğüne yönelik tehdit etme ve kuvvet kullanmaktan kaçınmak zorunda olması genel ilke olarak benimsenmiştir. ${ }^{3}$ Kuvvet kullanma yasağının önemli bir istisnası meşru müdafaadır. Uluslararası barış ve güvenliğin tehdit altında olması ${ }^{4}$ halinde $\mathrm{BM}$ Antlaşması 51.madde ile meşru müdafaa hakkı kabul görmüştür (BM Antlaşması, 1945; Çakmak, 2014: 29-185). Meşru müdafaa olarak tanımlanabilecek durumlarda devletlerin tek taraflı olarak kuvvete başvurabilecekleri BM Antlaşması'nda açık bir şekilde ifade edilmektedir. ${ }^{5} \mathrm{Bu}$ nedenle günümüzde SİHA'lar, meşru müdafaa kavramı ile birlikte sık sık bir arada kullanılırken işitilebilir. Nitekim SİHA'nın dünya gündeminde öne çıkışı, ABD'nin 11 Eylül saldırılarına maruz kalması sonrasında küresel ölçekte başlattığı terörle savaşı ile birlikte olmuştur. Bu süreçte ABD; 11 Eylül olayları sonrasında terörizmle savaş amacıyla BM Antlaşması'na istinaden meşru müdafaa hakkı beyanıyla, El Kaide bağlantılı örgütlere ve barındıkları ülke olan Afganistan'a müdahale etmiştir. Ardından önleyici meşru müdafaa hakkıyla Irak'a operasyon başlatmıştır. Müteakip süreçlerde ise dünya ölçeğinde Pakistan, Yemen, Suriye gibi ülkelerde askeri ve istihbarat operasyonlarını sürdürmüştür (Batır, 2011: 128-132). Dünyada bu savaş ve operasyonlar sürdürülürken SİHA'lar, temel silah sistemleri olarak geliştirilmeye ve kullanılmaya devam etmiş, ABD'nin yeni askeri stratejilerinin bir aracı haline gelmiştir. ABD, bu yıllarda Soğuk Savaş zamanının Sovyetler Birliği ve müttefiki ülkelere uyguladığı çevreleme ve caydırma politikasını terk etmiş, yeni tehditlerin asimetrik ve değişken özelliklerini dikkate alarak 2002 yılında ulusal güvenlik stratejisini değiştirmiştir. ABD, 2002 yılı Ulusal Güvenlik Strateji dokümanında uluslararası hukukta tartışmalı olan ön alıcı (preemptive) ve önleyici (preventive) müdahale kavramlarına yer vermiş, ön alıcı müdahale ile terör örgütleri gibi organizasyonları hesaba katarak bir hasım tarafından yapılmakta olan saldırı hazırlığına karşı saldırı yapmayı, onu etkisiz hale getirmeyi ve inisiyatifi ele geçirmeyi amaçlamıştır. Burada en önemli husus, düşmandan gelecek saldırının çok yakında ve kaçınılmaz olarak gerçekleşecek olmasıdır. Önleyici müdahale ile düşmanın tehditlerinin bilinmesiyle birlikte tehditlerin çok yakın veya belirginleşmiş olmadığı, bu nedenle kaçınılmaz duruma 
gelen bir çatışma öncesi ilk vuran olma kaygısı bulunduğu ancak uzun vadede düşmandan önce saldırıya geçme düşüncesini hâkim olduğu bir yaklaşımdır. Nitekim ABD'nin Afganistan'a operasyonu ön alıcı müdahale, Irak'a operasyonu önleyici müdahale kapsamında gerçekleştirilmiştir (US The White House, 2002: 15). ABD'nin benzer yaklaşımları terörle mücadele ettiği Pakistan, Yemen, Suriye, Somali, Cibuti gibi ülkeler ile Güneydoğu Asya ülkeleri olmak üzere dünyanın çeşitli coğrafyalarında SİHA operasyonlarıyla devam etmektedir. Uluslararası ortamda, ABD'nin müdahale hukuku bağlamında alan açarak öngördüğü bu doktrin ve yaptığı eylemler uluslararası hukuk açısından meşru savunma kapsamında kuvvet kullanmayı yasal kılan bir gerekçe olmadığı görüşü hâkimdir. (Vogel, 2011: 106; IHR \& CRC, 2012: 11-12; Woodhams \& Borrie, 2018: 18). Zira 2005 yılında meşru müdafaa ile SİHA kullanımının nasıl yapılacağıyla ilgili BM ve Uluslararası Adalet Divanı, hedeflerin ev sahibi ülkeye isnat edilmesi ve ilgili ülke tarafından barındırılması durumunda bu saldırıların gerekçe olabileceğini böyle bir durum olmaması durumunda ise ev sahibi ülkeden izin alınması ya da BM Güvenlik Konseyi ile iş birliğine yönelinmesi gerektiğine ilişkin karar ve raporlar oluşturmuştur ${ }^{6}$ (International Court of Justice, 2005: 85-105; Bethlehem, 2012: 7; UN, 2013). Ancak genel olarak uluslararası terör ve suç örgütlerinin başarısız devletler ile çöküş sürecine girmiş devletlerde barınmaları neden gösterilerek, önceden tedbir alma anlamına gelen müdahale hukuku meşrulaştırılabilmektedir. $\mathrm{Bu}$ yaklaşım, günümüzün dünyasında geleneksel ulus devletlerin egemenliği anlayışını içeren Westfalya döneminin koşullarının artık değiştiği, terör yuvalarını topraklarında barındıran ülkelerin egemenlik kavramının arkasına saklanamayacağı, eğer tehdit varsa bu devlete karşı ön alıcı müdahale olarak operasyon yapılabileceği düşünceleriyle desteklenmektedir (Dönmez, 2017: 10-14). ABD, her ne kadar SïHA kullanımının çatışma ve hukuk açısından konumunun belirlenmesinde istekli olduğu yönünde sözler sarf etse de, SïHA'lar vasıtasıyla gerçekleştirdiği bu operasyonların uluslararası hukukun seyrini değiştirmeyecek sadece ad hoc/amaca özel ihlaller olarak kalması yönünde temayülü olduğu görülmektedir. ABD'nin kuvvet kullanımında kendisine esneklik sağlayacak bu gibi durumların uluslararası hukuki metinlere girmesine ya da uluslararası teamül kuralları olmamasını istememesinin en önemli nedeninin, başka ülkelerin bu nedenleri kullanıp benzer müdahaleler gerçekleştirmesini önlemek olduğu açıktır (Batır, 2011: 132). Nitekim Birleşik Krallı̆̆ın ABD’yle birlikte yaptığı müşterek SİHA operasyonlarında duyduğu çekinceler ve rahatsızlıklar 
Silahlı İnsansız Hava Araçlarının Uluslararası Alanda ve İç Güvenlikte

Sevk ve İdaresine İlişkin Hukuki Saptamalar

bununla anlaşılabilir. Birleşik Krallık içerisinde farklı siyasi taraflar, ABD tarafından kabul gören meşru müdafaa hakkının geniş yorumlanmasıyla amacını aştığını değerlendirmektedir. $\mathrm{Bu}$ nedenle Birleşik Krallığa, ABD ile terörle mücadele için müşterek icra edilen SİHA operasyonlarına katılım sağlanması durumu ve burada görev alan Birleşik Krallık askeri personelinin risk aldığ 1 yönünde eleştiriler getirilmektedir (Holloway vd., 2018: 36).

Uluslararası hukuk açısından kuvvet kullanılması sırasında ifade edilmesi gereken diğer bir konu da kullanılan silah ve sistemlerin ister SİHA veya başka bir silah sistemi olsun, bir operasyonda hedeflerin yasallığ ve meşruluğu konusudur. Bunlar, uluslararası silahlı çatışma/insani hukuk kapsamında gelişen ve sivillerin korunmasının uygunluğunu benimseyen hukuki çerçevelerdir. Bu hukuki metinler İkinci Dünya Savaşı'ndan sonra savaşın insancıllaştırılması yönünde adımlarla daha fazla hız kazanmıştır. Hukuki metinler açısından La Haye sözleşmeleri, silahlı çatışmaların sevk ve idaresi, işgal ve tarafsızlık hukuku kurallarına ilişkin mevzuatı oluştururken; Cenevre Sözleşmeleri içerisinde, silahlı çatışmalar nedeniyle savaş esirleri, yaralı ve deniz kazazedeleri, ölüler, sağlık ve din personeli gibi savaş mağdurları ile ilgili hususlar düzenlenmiştir. New York'ta yapılan sözleşmeler ise, BM Antlaşması ile BM Teşkilatı kapsamında ortaya çıkan metinlerdir. ${ }^{7}$ Günümüze kadar gerçekleştirilen mevzuata bakıldığında, silahlı çatışma kavramının; devletlerarasında gerçekleşen ve savaşın niteliğini de kapsayıcı bir kavram olarak kullanılması yanında, taraflardan birinin uluslararası örgüt olduğu silahlı çatışmalar, bir devletin hükümet kuvvetleri ile hükümete karşı gelen silahlı gruplar arasındaki silahlı çatışmalar ya da bir devlet içerisinde değişik silahlı gruplar arasındaki silahlı çatışmaların hepsinin içine alan bir yapıya dönüştüğü ifade edilebilir. Bu çerçevede çatışma şekillerine göre silahlı çatışmalar; (1) devletlerin topyekûn mücadelesine karşılık gelen savaş boyutu ve (11) bu düzeyde savaşa varmayan sınırlı silahlı çatışmalar olarak ikiye ayrılmaktadır. Nitekim, bu kapsamda hazırlanan 1949 tarihli Cenevre Sözleşmelerinin 2'nci maddesinde yukarıda ifade edilen bu çatışma halleri için insancıl hukuk kuralları esasa bağlanmıştır (Aslan, 2008: 25; Yamaner vd., 2008: 2-26-50).

Hukuki çerçevesi belirlendiği üzere, silahlı çatışma hukuku, bir silah sistemi ve aracı olarak SïHA'ların kullanım şeklini ve alanlarını da doğrudan etkilemektedir. Ancak günümüze kadar gelen süreç içerisinde SİHA'lar, hem bir 
silah ve sistem olarak hem de silahlı çatışma hukuku ya da devletlerin iç hukuku bağlamında tanımlanmamıştır. Özellikle SİHA'ların; (1) tank, obüs, top ve nükleer başlıklı silahlar gibi topyekûn savaşta kullanılan ve konvansiyonel etkisi olan bir savaş aracı olarak görülmemesindeki yatkınlık ve (11) doğrudan bireysel bir eyleme ya da düşmanca örgütlü bir çabaya ani ve sınırlı müdahale edebilirliği silahlı çatışma hukuku gibi mevzuata uygunluğunu zorlaştırmaktadır. Silahın kullanım yeri ve amacı hukuki tespitler açısından önemlidir. Zira bu hukuki tespitler, modern devletlerin hukuk devlet sistemine etki edebilmektedir. Buna örnek olarak ABD'nin SiHA operasyonları gösterilebilir. Modern devletlerde teamüller gereği yurt dışında askeri güç kullanımının yasal onayı için parlamentodan yetki alınmaktadır. Ancak son yıllarda ABD ve Birleşik Krallık gibi ülkelerin Afganistan, Irak, Libya ve Suriye gibi iç çatışmaların yaşandığı bölgelerde SİHA'ların kullanımına ilişkin parlamentolarından yetki almama eğilimi gösterdikleri bilinmektedir. Bu durumlar ise; Birleşik Krallık ve ABD’nin müşterek hareket edilen SİHA operasyonlarının gözetim ve hesap verilebilirliği açısından kendi kamuoylarında eleştirilere sebep olmaktadır (Holloway vd., 2018: 35).

İkinci Dünya Savaşı'ndan sonra savaşın yıkıcı etkilerinin tekrarının yaşanmaması için 2 Ağustos 1949 tarihinde Cenevre Sözleşmeleri ve bu sözleşmelere ek olarak 1977 yılında oluşturulan silahlı çatışma ve uluslararası olmayan silahlı çatışmalarda mağdurların korunmasına ilişkin protokoller hazırlanmıştır. İlki, devletlerarasında silahlı kuvvetlerin çatışmasına karşılık gelirken; ikincisi, bir devlet ile örgütlü silahlı grup veya iki ve daha fazla örgütlü silahlı gruplar arasındaki şiddetli silahlı çatışmalara ilişkindir. SİHA'ların kullanımına ilişkin usuller her ikisi için de geçerli olmakla birlikte dünyada en tartışılır hali, bir devlet ile örgütlü silahlı grup veya iki ve daha fazla örgütlü silahlı gruplar arasındaki şiddetli silahlı çatışmalara ilişkin olan durumudur. Son yıllarda Birleşik Krallığın ABD ile birlikte dünyanın çeşitli yerlerinde gerçekleştirdiği SİHA operasyonlarının kendi içerisinde tartışmasının nedeni de budur. Birleşik Krallığın Afganistan, Irak ve Suriye'de DEAŞ'la yapılan mücadelelerinin silahlı çatışma hukuku açısından uluslararası olmayan silahlı çatışmalara yönelik olduğu kanaati hâkimdir. Birleşik Krallıkta; farklı siyasi taraflar ABD ile müşterek yapılan SİHA operasyonlarına ilişkin olarak, eylemlerin küresel ölçekte birden çok ülkeyi hedef alması, bu ülkelerde herhangi bir uluslararası çatışma ve savaşın olduğu yönünde BM'nin kararının bulunmaması ve uluslararası bir uzlaşmanın sağlanmaması konularında endişelidir. Bu açıdan kendilerinin ABD ile müşterek 
Silahlı İnsansız Hava Araçlarının Uluslararası Alanda ve İç Güvenlikte

Sevk ve İdaresine İlişkin Hukuki Saptamalar

icra ettikleri SIHA operasyonlarında hedefler açısından temel alınacak mevzuatın 12 Ağustos 1949 tarihli Cenevre Sözleşmelerine Ek Uluslararası Olmayan Silahlı Çatışma Mağdurlarının Korunmasına İlişkin 2 Numaralı Protokol olması gerektiği savunulmuştur (Holloway vd., 2018: 37-38).

Silahlı çatışma hukukunda temel prensip, kimlerin hedef olacağı ve bunun için savaşanlarla sivillerin ayırt edilebilirliği olan ayrım ilkesidir. Ancak Afganistan, Irak ve Suriye'deki SïHA operasyonlarında bu silahl grupların tespiti ile sivillerin ve savaşçıların ayırt edilmesinde zorlanıldı̆̆ı bir gerçektir. Terörist grupların gevşek organizasyon yapısı, üniforma kullanmamaları, sivilleri de kasıtlı olarak kalkan yapmaları bu ayrım ilkesinin uygulanabilirliğini zorlaştırmaktadır. Yine de SİHA'ların gelişmiş gözetim yeteneklerinin kullanarak tespit ve tanımlama standartları geliştirmeleri ve bunun için yeterli zamanı sağlayabilmeleri önemli bir avantaj olarak görülmektedir (Holloway vd., 2018: 38). Hukuki açıdan kimin silahlı bir grubun üyesi olduğuna ilişkin olarak Uluslararası Kızıl Haç Komitesi, savaşta sürekli bir işlevi olanların silahlı bir grubun üyesi kabul edilebileceğini belirtmektedir. Bunun için hedeflerin belirlenirken doğrudan katılım sağlayanlara yönelik kanıtlara odaklanılmasını önermektedir. Bu sayede örgütle doğrudan bağlantılı olanların akrabaları ve örgütle dolaylı bağlantısı olanların korunabileceği kabul edilmektedir. Sivillerin doğrudan saldırılara karşı korunması gerektiği, düşmanlık yapmadıkça veya bu eylemi belirli bir süre yapanların düşmanlıkta yer almadıkları süre içerisinde hedef alınmaması görüşü savunulmaktadır. Uluslararası Kızıl Haç Komitesi, eğitim ve lojistik desteğe katılanların meşru hedefler olmadığı, ayrıca doğrudan bir saldırıya katılsa bile hedeflenen zamanda eylemde bulunmayanların hedef olamayacağını değerlendirmektedir (Melzer, 2009: 32-33; Holloway vd., 2018: 38). Ancak bu kriterlerin belirsizlikleri ortadır. Nitekim buna muhalif değerlendirmeler de bulunmaktadır. Örneğin, İsrail Mahkemeleri 2006 yılında fiziksel saldırı dışında yardımda bulunan, istihbarat bilgisi toplayan, ulaştırma faaliyetlerinde bulunanlar gibi düşmanca eylemler içine katılanların SİHA hedefi olabileceği konusunda hukuki boyutu genişletmiştir (Ak, 2017: 43).

Diğer taraftan, Birleşik Krallık içerisinde yer alan siyasi taraflar silahlı çatışmaların olmadığı ülkelere yapılan SïHA operasyonlarının silahlı çatışma hukukuna yükümlü olamayacağını, bu haliyle Avrupa İnsan Hakları Sözleşmesi'ni (AİHS) imzalamış bir ülke olarak AİHS'ye yükümlü kılınması gerektiğini 
vurgulamaktadırlar. İfade edilmek istenen, eğer operasyon silahlı çatışma içerisinde değerlendiriliyor ise silahlı çatışma hukuku geçerlidir. Eğer bu sayılmıyor ise, kuvvet kullanımlarına ilişkin kuralların uluslararası insan hakları hukuku bağlamında kabul edilmesi önerilmektedir. AİHS'nin 2.maddesi yaşamın kasıtlı olarak yoksun bırakılmasını yasaklamaktadır ve öldürme yetkisi silahlı çatışma hukukuna göre daha sınırlıdır (Holloway vd., 2018: 41). AİHS'nin 2.maddesi, devletin birisini yanlış şekilde öldürdüğü iddia edildiğinde bağımsız ve tarafsız bir soruşturmayı gerekli kılmaktadır (Council of Europe, 2010: 6). Bu nedenle, AİHS'nin insansız hava saldırıları için geçerli kılınması durumunda, Birleşik Krallığı yerel mahkemeler veya Avrupa İnsan Hakları Mahkemesi önemli miktarda tazminat talep etme ve sözleşme hükümlerini ihlal ettiğine ilişkin kararlara maruz bırakabilir (Holloway vd., 2018: 38-41). Günümüzde SİHA’ların uluslararası alanda kullanımıyla ilgili olarak sözü edilen ve var olan tartışmalar iç güvenlik boyutuna taşınarak da devam edilebilir.

\section{SİHA’ların İç Güvenlikte Kullanımına İlişsin Tespitler}

İHA'ların iç güvenlikte kullanılmaya başlanması son on yılda gelişme göstermiştir. Hâlihazırda ABD'de farklı tip ve modelde İHA'lar; ülkenin güneyinde sınır güvenliğinde, keşif maksatlı özel harekât operasyonlarında, suç mahallinin analizinde, kalabalıklar arasında suç takibinde, yangınlara müdahale ve arama kurtarma faaliyetlerinde, kritik altyapıların izlenmesinde, afetlerde yardım ve acil tıbbi malzemelerin uzak yerlere taşınmasında, kentlerde trafik sıkışıklarının izlenmesinde yoğun biçimde kullanılmaktadır (Graham, 2011: 18; Pejic, 2015: 1; Homeland Security, 2017; Tucker, 2017; Margaritoff, 2017; Alderton, 2018). Özellikle İHA'ların istihbarat, gözetleme, keşif maksatlı kullanılıyor olması vatandaşlara gözetleniyor hissi yarattığından olumsuz psikolojik etkisi olduğu konusunda eleştiriler getirilmektedir. Özellikle ABD ve Avrupa Kıtasında etik bağlamda mahremiyet haklarını veya AİHS'ni ihlal edip etmediği konusunda kaygilar dile getirilmektedir (Pilkington, 2014; Stanley, 2017; Holloway vd., 2018: 42).

Diğer taraftan modern devletin ayrıcalığı olan özgürlük imkânlarından çoğunlukla terör ve örgütleri de yararlanır. Ülkelerin demokratik yapısından gizlilik içerisinde faydalanmayı ve suistimali arzulayan terör ve suç örgütlerinin modern devletleri önümüzdeki on y1llarda daha rahatsız edeceği ve demokratik 
Silahlı İnsansız Hava Araçlarının Uluslararası Alanda ve İç Güvenlikte

Sevk ve İdaresine İlişkin Hukuki Saptamalar

devletlere özgü bir sorun olarak kalmaya devam edeceği açıtır. Bu bağlamda SİHA'ların terörle mücadele başta olmak üzere iç güvenlikte kullanılması, uluslararası alanda kullanılmasında karşılaşılan benzer tartışmalar gibi yeni bir süreçtir (Woodhams \& Borrie, 2018: 2). SİHA'ların teröre maruz kalan ülkeler tarafindan, terörle mücadele yöntemlerinden birisi olarak gerek mekânsal boyut gerekse zaman ve ateş üstünlüğü bakımından kullanılması kuşkusuz asimetrik bir avantaj yaratır. Özellikle kent, kasaba gibi yerleşim yerleri dışında kırsal bölgelerde siviller ile teröristlerin ayrılmasına imkân sağlayan ve terör faaliyetleri gösteren örgütlerin daha kolay tanınabileceği yerlerde yeni mücadele tekniği olarak görülebilmektedir.

Hukuk, demokrasi, birey ve insan hakları merkezli değerler sistemine sahip olan toplumlarda, terörle mücadele ancak bu değerler ölçüsünde yapılması gerektiğinden devletlerin bu konuda en önemli gücü, haklılığı ve meşru olmasıdır. $\mathrm{Bu}$ nedenle güvenliğin sağlanması için alınan tedbirlerin amacı, hem devletin kendi varlık ve bütünlüğünün hem de vatandaşlarının psikolojik ve fiziksel kazanımlarının zarar görmesini engellemeye yönelik olmalıdır (Ergül, 2014: 71). Modern bir devlette bir ülkenin egemenlik sınırları dâhilinde iç güvenliğin sorumluluğu kolluk kuvvetlerindedir. Devlet bu sorumluluğa istinaden kabul ettiği uluslararası sözleşmeler, anayasa, oluşturduğu kanunlar ve buna bağlı alt mevzuatı ile kolluk kuvvetlerine zor kullanma ve silah kullanma yetkisi verir. Bunun ölçüsünün sertliği ve serbestliği veya yaptırım gücünün genişliği ve çeşitliği o ülkenin içinde bulunduğu ekonomik, toplumsal, siyasal ve kültürel ortamına göre çeşitlilik gösterir, devletin vatandaşlarının haklarının korunmasına ilişkin teminatlara göre değişebilir. SİHA'nın iç güvenlikte kullanımı ve kolluk açısından bir yöntem olarak belirlenmesi en nihayetinde siyasi iradenin bir tercihidir ve niyet beyanı göstererek araçların sınırlılıklarını belirleyebilir.

Ülkesinde terörle mücadele eden bir devlet açısından uygulanacak hukuki standartlar çatışmaların şiddetine bağlı olmakla birlikte üç seviyeye ayrılabilir. İlk durum, sınırlı olay ve çapta eylemlere yönelik hayatın normal akışı içinde insan hakları hukukunun uygulanarak mücadele edilmesidir. İkincisi, devletlerin olağanüstü hal durumuna geçmesi, insan haklarını korumak ve temin etmekle birlikte daha sınırlayıcı tedbirleri yürürlüğe koyması ve mücadele tedbirlerini genişletmesidir. Üçüncü ise, ülke içinde silahlı çatışma şartları oluşması ve 
uluslararası silahlı çatışma/insancıl hukukun uygulanabilir olmasıdır. Bu aşamalar aslında iç çatışmanın şiddeti ve ülke içerisinde mücadele edilirken uygulanacak insan hakları ile insani/çatışma hukukunun kullanım şekline göre derecelendirilmesidir. Günümüzde birçok devletin mücadele yöntemi, terör örgütleriyle insan hakları hukuku bir diğer deyişle anayasası bağlamında hazırlanan ceza hukuku ve cezai adalet modelidir. Ülkeler, terör örgütlerine meşruiyet kazandırmamak ve bir siyasi aktör olarak muhatap olunmaması için silahlı çatışma hukuku yerine mevcut insan hakları hukukuna bağlı kalmayı tercih ederler. Diğer taraftan bu değerlendirmelerin, her iki hukuki çerçeveye yönelik uluslararası antlaşmaları imzalayan ülkeler açısından geçerli olduğu da unutulmamalıdır. ${ }^{8}$ İkinci Dünya Savaşı sonrası 1940'lı yıllarda silahlı çatışma hukuku ile insan hakları hukukunun hazırlık seyri izlenirken insan hakları hukukunun, silahlı çatışma durumunda uygulanamayacağı öngörüsü ile 1948 yılı İnsan Hakları Evrensel Beyannamesi ve 1949 yılı Cenevre Sözleşmeleri birbirlerinden ayrı olarak hazırlanmıştır. Genel olarak, 1949 yılı Cenevre Sözleşmelerinin ortak yazılmış 3.maddesinde işaret edilen hususlar ${ }^{9}$ ile temel insan hakları gereksinimleri arasında örtüşme olmasına rağmen silahlı çatışma hukukunun daha çok eski sömürge toplumları ve BM çerçevesinde kaderlerini tayin hakkını kullanmak isteyen SSCB ile Afrika topluluklarına yönelik benimsenmesi görüşü hâkim olmuştur. Günümüze kadar İngiltere-IRA, İspanya-Bask, Fransa-Cezayir Ulusal Kurtuluş Cephesi veya Rusya-Çeçenistan arasında terör tehditleri oluşmuş, bunlar silahlı çatışma/insani hukuk kapsamında görülmemiş ve iç güvenliği ilgilendiren olaylar olarak kabul edilmiştir (Ökten, 2015, 2-19).

$\mathrm{Bu}$ kapsamda iç güvenlikte terörle mücadeleye ilişkin uygulanacak insan hakları hukukunun ve mücadele yönteminin, uluslararası alanda onaylanan mevzuata, anayasaya ve kanunlara uygun silah kullanma yetkisi ile düzenlendiği söylenebilir. Örneğin Avrupa İnsan Hakları Mahkemesi (AİHM), AİHS'de belirtilen devletin kullanacağı ölümcül gücü ayrıntılı bir yaklaşımla yorumlamasına rağmen, ${ }^{10}$ AİHS'nin 2.maddesi ${ }^{11}$ kolluğun, koşulları belirli durumlarda ölümcül güç kullanmasını meşru görmektedir. Bu yetkinin sınırları uluslararası sözleşmeler, Anayasa ve kanunlar çerçevesinde oluşturulurken, temel haklarla ilgili sınırlamalarda da kanunla belirlenir. Silah kullanma, ancak kamu düzenini ve güvenliğini bozacak nitelikteki gerçek bir tehlikenin varlığ 1 halinde, kesin zorunluluk söz konusuysa meşru ve mazur görülebilir. BM Kanun Adamlarının Zor ve Silah Kullanmalarına Dair Temel Prensipler 9.maddesinde ölümcül güç 
Silahlı İnsansız Hava Araçlarının Uluslararası Alanda ve İç Güvenlikte

Sevk ve İdaresine İlişkin Hukuki Saptamalar

kullanma yetkisine genel olarak kolluk kuvvetlerinin kendilerinin ve başkalarının öldürülmelerine veya ağır bir biçimde yaralanmalarına yönelik yakın bir tehlikeye karşı müdafaa halleri ile yaşama karşı ağır bir tehdit içeren ağır nitelikteki özel suçların işlenmesinin önlenmesi amacıyla silah kullanılmasını öngörmüştür (Sevük, 2012: 248-255). Tehditlerin yakınlığ ve hayati tehlikelerin işlenmesinin önlenmesi gibi hususlar ile meşru müdafaa gereksinimlerinin ne olunduğunun bilinmesi SïHA kullanıcı ve karar vericiler için önemlidir. SİHA'nın kullanımında kolluk, sahip olduğu diğer silah kullanma yetkileriyle benzer şekilde terörle mücadele ve olağanüstü hâl kanunlarına uygun biçimde gereklilik, ölçülülük ve orantılılık usullerine uygun meşru müdafaa gereksinimlerini karşılamalıdır. ${ }^{12}$ Gereklilik, teröristin ölümcül tehditlere sebep olacak şekilde tehdidin yakın tehdit olmasıdır (Pejic, 2015: 37; Holloway vd., 2018: 39). Ayrım ilkesi, aracın teknolojik özelliklerinden faydalanılarak hedefin doğruluğunun tespiti yanında, terörle mücadele edilen bölgenin vatandaşların günlük yaşamını sürdürdüğü coğrafyalardan güvenli alan ve benzeri yöntemlerle ayrı tutulması ile sağlanabilir. Ölçülülük ilkesi ise, tespit edilen hedefin elindeki silahlar ile yaratacağı olumsuz etkinin değerlendirilmesine göre belirlenmektedir.

\section{Sonuç}

Günümüzde SïHA'ların keşif, gözetleme ve bir silah sistemi olarak zaman ve mekâna sahip olma avantajı, asimetrik etki ve uygun maliyet açısından ülkelere önemli üstünlük kazandırdığı inkâr edilemez. Bunun en önemli kanıtı; geçen yıllar içerisinde bu araçların istenen performans ve işlevlerine bağlı olarak farklı boy ve ebatta tasarlanmaları, taşıdıkları silah ve mühimmatın çeşitliliğine göre araç ailesinin genişletilmesidir. SİHA'ların ülke politikaları ve askeri operasyonları için can kaybı ve ciddi ekonomik maliyet yaratmaması ülkelerin kamuoyları tarafindan da olumlu karşılanmaktadır. SİHA'ların devletlere sağladığı bu imkânlar sayesinde kullanımının önümüzdeki yıllarda daha da teşvik göreceği açıktır. Araçlara gösterilen bu ilgiye rağmen hukuki ve etik bağlamda değerlendirmeler daha yavaş bir seyir izlemektedir. Bu ilginin azlığı, uluslararası alanda çatışmaların değişen özellikleri, SIHHA'ların devletler için terörle mücadele seçenekleri başta olmak 
üzere politik ve askeri kullanım çeşitliliğine yol açması ve teknolojinin hızlı seyir izlemesidir.

SİHA'ların kullanımıyla ilgili tartışmalar şimdilik muğlak bir zeminde ilerlemektedir. ABD'den Çin'e İsrail'den AB ülkelerine kadar fiili normlar yaratılarak emsaller oluşmaktadır. Önümüzdeki dönemde uluslararası, ulusal ve iç güvenlik alanında bu araçların kullanımı ve bilinerbilirliğinin artması, hem kuvvet kullanımına karar verme açısından hem de hedef ve yöntem belirleme bağlamında tartışmalara çözüm bulunmasına katkı sağlayacaktır.

\section{Extended Summary}

Nowadays, it cannot be denied that AUAVs which make exploration and surveillance as a weapon system grant privileges to countries that possess them in terms of terrestrial and air dominance in combat, responding to threats quickly, asymmetrical effect and cost-effectiveness. The most important proof of this is that these vehicles are designed in different lengths and shapes depending on the desired performance and functions. Moreover, depending on the variety of weapons and ammunition they carry, vehicle families have been expanded. It is welcomed by publics of countries that AUAVs do not cost people operating them their lives, nor do they cause serious economic burden. It is clear that the use of AUAVs will provide more incentives in the coming years. Despite this interest in the aircraft, legal and ethical evaluations follow a slower course. Considering the reasons for this lack of interest, one can say: (i) The changing characteristics of the conflicts in the international arena. (ii) The contribution of AUAVs to diversity in political and military actions, particularly for counter-terrorism options for countries. (iii) The rapid change of technology. Discussions on the use of AUAVs are now on a vague ground. According to the methods of use from USA and China to Israel and EU countries, actual norms and precedents are formed. In the upcoming period, the use and recognition of these vehicles in the field of international, national and internal security will increase. This will contribute to both decision making in terms of use of force, and goal and method determination. To give an example, it is seen that the United States uses four different methods for the purpose of exploration and hitting targets in the international field. Looking at these; (1) such as in Afghanistan, AUAV and UAV operating in foreign airspace with permission where potential hostiles are present. (11) Operating in foreign 
Silahlı İnsansız Hava Araçlarının Uluslararası Alanda ve İç Güvenlikte Sevk ve İdaresine İlişkin Hukuki Saptamalar

airspace without permission and without the foreign country's capability to respond, like Mali (111) operating in disputed international airspace near a foreign power with the capability to respond, like China (1v) operating in foreign airspace without permission and the country's capability to respond, like Iran and Pakistan (Schaus \& Johnson, 2018: 3-9). For the use of AUAVs in internal security; human rights law, international legislation, the constitution and the law are prepared in accordance with the authority. In the case of internal security, surveillance and use of weapons of AUAVs are regulated in accordance with human rights law, international legislation, constitution and laws. There are basic features that distinguish these armed vehicles from others. These can be expressed as follows: (i) The ability of decision-makers to follow and contribute to the process of where and how the AUAV firing will take place. (ii) Possibility of minimizing the damage to civilians due to the advantage of staying airborne on the target longer compared to manned aircraft. This article aims to understand today by making observations in the ethical and legal contexts, as it will be seen in the coming years that the AUAVs will be used more and more. In this way, it is considered that new approaches to both national security and internal security can be benefited. Foreseeing the international and national use of these vehicles will contribute to the preparedness for the effects of these technologies for life in modern society.

\section{Son Not}

${ }^{1}$ SİHA'lar ve özelliklerine ilişkin kapsamlı açıklamalar için ayrıca bakınız: T. Ak (2017). Günümüzün Değişen Çatışma Koşullarında İnsansız Savaş Araçları ve Etik Tartışmalar, Sistem Ofset Yayıncılık, Ankara.

${ }^{2}$ SiHA kullanımında farklı karar mekanizmaları ve işlevleri için ayrıca bakınız: T. Ak (2018). Silahlı İnsansız Hava Araçlarının Kullanımında Karar Mekanizmaları, Güvenlik Bilimleri Dergisi, 7 (1), 111-130.

${ }^{3}$ BM Antlaşmasının 2, 33 ve 37'nci maddeleri konuya ilişkin maddeleridir.

${ }^{4}$ Ancak uluslararası barışın ve güvenliğin tehdit altında olup olmadığının tespiti, 39. madde ile BM Güvenlik Konseyi'ne verilmiştir (BM Antlaşması, 1945; Çakmak, 2014:186).

${ }^{5}$ Yukarıda da belirtildiği gibi BM sisteminde amaçlanan, kuvvet kullanımının devletler açısından tek taraflı bir seçenek olmamasının sağlanmasıdır. BM Şartının 
51.maddesi ise kuvvet kullanma yasağının meşru müdafaa hakkının ortadan kalkması şeklinde yorumlanamayacağını belirterek devletlerin istisna hallerinde, yani meşru müdafaa durumunda kuvvete başvurabileceklerini dolaylı olarak kabul etmektedir. Maddede dikkat çeken nokta meşru müdafaa tedbirlerine başvurulabilmesi için bir silahlı saldırının meydana gelmiş olması gerektiğidir. Yani ortada henüz bir silahlı saldırı yoksa meşru müdafaa hakkının ortaya çıktığından bahsedilemiyor olması gerekmektedir. Bir diğer önemli sınırlama da bu meşru müdafaa halinin ancak BM Güvenlik Konseyi'nin harekete geçmesine kadar devam ediyor oluşudur. Meşru müdafaanın genel çerçevesine bakıldı̆̆ında, verilen karşılığın saldırı ile orantılı olmasının gerektiği de söylenebilir. Bir başka koşul da saldırıya uğrayan devletin, aldığı meşru müdafaa tedbirleri ile ilgili olarak BM'yi bilgilendirmesi zorunluluğudur. Meşru müdafaanın bir hak olarak ortaya çıkabilmesi için ise gereklilik ve orant1l11lk ilkelerinin yerine getirilmesi gerekmektedir (Çakmak, 2014:191-192).

62013 yilında Raportör Bem Emmerson tarafindan hazırlanan "Terörizmle Mücadelede İnsan Haklarının ve Temel Özgürlüklerin Teşvik Edilmesi ve Korunmasına İlişkin Özel Rapor”a ve Uganda'nın Demokratik Kongo Cumhuriyeti toprakları üzerinde 1998 yılından itibaren işgal, askeri faaliyet ve eylemlerine ilişkin olarak Uluslararası Adalet Divanı tarafından hazırlanan Uganda ve Demokratik Kongo Cumhuriyeti arasındaki "Kongo Toprakları Üzerinde Askeri Eylemlere İlişkin Dava Raporuna ayrıca bakınız: UN (2013). Report of the Special Rapporteur on the Promotion and Protection of Human Rights and Fundamental Freedoms While Countering Terrorism, A/68/389, 18 September 2013, https://unispal.un.org/DPA/DPR/unispal.nsf/0/2DAADAFC4682762585257C0B00 60

${ }^{7}$ Savaşın yasaklanması ya da en azından savaşın doğurduğu zararların en aza indirilmesini amaçlayan ve Birinci Dünya savaşına kadar olan dönemde gerçekleştirilen sözleşmeler, 1856 yılı Paris Deniz Hukuku Beyannamesi ile başlamış ve 1864 yılında Cenevre'de imzalanan Savaş Alanında Yaralıların Durumunun İyileştirilmesi Sözleşmesi ve müteakiben diğer sözleşmelerle devam etmiştir. La Haye sözleşmeleri ise 1899 yılında oluşturulmaya başlanmış, 1907 yılında da yeni metinler eklenmiştir. İkinci Dünya Savaşı'na kadar olan dönem ile savaş sonrası dönemlerde sözleşmelerin hazırlanmasına devam edilmiştir. Silahlı çatışma hukuku kapsamı içerisinde sayılan La Haye, Cenevre ve New York 
Silahlı İnsansız Hava Araçlarının Uluslararası Alanda ve İç Güvenlikte

Sevk ve İdaresine İlişkin Hukuki Saptamalar

sözleşmelerinin neler olduklarına ilişkin ayrıntılı bilgi için ayrıca bakınız: Y. Aslan (2008). Savaş Hukukunun Temel Prensipleri, TBB Dergisi, (79), 235-274.

${ }^{8}$ Örneğin Türkiye, 1949 y1lı Cenevre Sözleşmelerini 10 Şubat 1954 tarihinde onaylamış, bu sözleşmelere ek olarak hazırlanan 1977 y1lı Ek I. Protokole (2 Ağustos 1949 tarihli Cenevre Sözleşmelerine Ek Uluslararası Silahlı Çatışmaların Mağdurlarının Korunmasına İlişkin Protokol) ve II. Protokole (12 Ağustos 1949 tarihli Cenevre Sözleşmelerine Ek Uluslararası Olmayan Silahlı Çatışmaların Mağdurlarının Korunmasına İlişkin Protokol) taraf olmamıştır. 2005 yılında imzalanan III. Protokolü (12 Ağustos 1949 tarihli Cenevre Sözleşmelerine Ek ve İlave Bir Ayırt Edici Ambleme İlişkin Protokol) I. ve II. Protokollere taraf olmadığını hatırlatan bir bildirim eşliğinde 7 Aralık 2006 tarihinde imzalamıştır. Ayrıntılı olarak bakınız: M.B. Yamaner, E. Öktem, B. Kurtdarcan, M.C. Uzun (2008). 12 Ağustos 1949 Tarihli Cenevre Sözleşmeleri ve Protokolleri, Galatasaray Üniversitesi Hukuk Fakültesi Yayınları Nu:42, İstanbul.

91949 y1lı Cenevre Sözleşmeleri ortak 3.maddesinde milletlerarası mahiyette olmayan bir silahlı anlaşmazlıkların taraflardan birinin topraklarında olması halinde çatışmaya doğrudan iştirak etmeyenlerin korunmasına yönelik maddeleri içermektedir (Yamaner vd, 2008: 2-26-50).

10 AİHM, güvenlik güçlerinin benzer güç kullanımları sırasında meydana gelen ölüm olaylarının soruşturulmasını sıklıkla ele alınmaktadır. Bu kapsamda, kararlarında güvenlik güçleri tarafından yürütülen operasyonlar sırasında meydana gelen ölümlerde güvenlik birimlerinin yetersiz planlama, tedbirsizlik, dikkatsizlik, orantısız, öldürücü olabilecek güç kullanımına işaret etmiştir. AİHM, suikast hazırladıklarından şüphelenilen üç IRA teröristinin güvenlik güçlerince öldürülmesinin söz konusu olduğu McCann/İngiltere davasında operasyonun zora başvurma gereğini imkân ölçüsünde asgariye indirecek surette hazırlanıp hazırlanmadığı hususunu incelemiştir. Mahkeme, olayda terörist olarak tanınan kişileri zararsız hale getirmekle görevli asker kişilerin, kendilerine verilmiş bulunan bilgiler 1şığında, teröristlerin uzaktan kumandalı bombayı patlatarak çok sayıda insanın ölümüne neden olmalarını önlemek için bu kişilere ateş açmanın mutlak surette gerekliliğine inanmıştır. Üstlerinden aldıkları emirlere uyarak, başkalarının hayatını korumak için bunun mutlak zorunluluk teşkil ettiği inancıyla görevlerini yerine getirdiği düşüncesindedir. Mahkeme, somut olayda görevlilerin 
olay anında karşı karşıya kaldıkları ikilemin göz önünde tutularak, kolluk görevlilerinin sadece o andaki fiillerini değerlendirmek suretiyle madde hükmünün ihlali konusunda bir sonuca varmanın yeterli olmadığını, aynı zamanda bütünü içinde antiterörist operasyonun AİHS 2.madde gereklerine uygun şekilde hazırlanıp hazırlanmadığının da incelenmesinin önemini vurgulamıştır. Bu husus askerlere verilip uygulandıklarında ölümle neticelenebilecek kuvvet kullanımını kaçınılmaz kılan talimat ve bilgilerin, olayda yer alan üç teröristin yaşam hakkını gereğince göz önünde tutup tutmadığı sorununu ortaya çıkarmıştır. Bu olayda Mahkeme, başkalarının hayatını korumak amacıyla üç teröristin öldürülmesinin mutlak gereklilikle kuvvete başvurma teşkil etmediği böylece 2.madde hükmünün ihlal edildiği sonucuna varmıştır. AİHM, kolluk görevlilerince operasyon planlanırken, öldürücü yöntemler ve öldürücü olmayan yöntemler arasında bir ayırım yapılarak öldürücü olmayan yöntemlere başvurulacağı, şüphelileri canlı olarak yakalamanın yolları ve teslim olma konusunda nasıl anlaşma yapılacağı gibi hususların belirlenmesini istemiştir. Aksi durumda teslim olmaya gönüllü olabilecek kişilerin yaşamlarının tehlikeye atılmış olacağını değerlendirerek bu durumda da müdahalenin orantılı olmadığını kabul etmiştir (European Court of Human Rights, 1995; Cengiz, 2011, 387; Sevük, 2012: 274).

${ }^{11}$ AİHS'nin Yaşam Hakkı başlıklı 2.maddesinde herkesin yaşam hakkının yasayla korunması belirtilmekle birlikte, ayaklanma veya isyanın yasaya uygun olarak bastırılması sırasında zorunlu olanı aşmayacak şekilde güç kullanılması sırasında oluşan ölüm gibi durumların madde ihlali olmadığı vurgulanmaktadır (Council of Europe, 2010: 6).

${ }^{12}$ Terörle mücadelede meşru müdafaaya ilişkin örnekler için bakınız: H. Y. Sevük (2012). Kolluk Görevlilerinin Silah Kullanma Yetkisi ve Yaşam Hakk, Yeditepe Üniversitesi Hukuk Fakültesi Dergisi, 2 (2), 274.

\section{Kaynakça}

\section{Kitaplar}

Ak, T. (2017). Günümüzün Değişen Çatışma Koşullarında İnsansız Savaş Araçları ve Etik Tartışmalar, Sistem Ofset Yayıncılık, Ankara.

Çakmak, C. (2014). Uluslararası Hukuk: Giriş, Teori ve Uygulama Bir Uluslararası İlişkiler Yaklaşımı, Ekin Basım Yayın Dağıtım, Bursa. 
Silahlı İnsansız Hava Araçlarının Uluslararası Alanda ve İç Güvenlikte

Sevk ve İdaresine İlişkin Hukuki Saptamalar

Graham, S. (2011). Kuşatılan Şehirler Yeni Askeri Kentçilik, çev. Levent Aydeniz, Nota Bene Yayınları, Ankara.

\section{Makaleler}

Ak, T. (2018). Silahlı Insansız Hava Araçlarının Kullanımında Karar Mekanizmaları, Güvenlik Bilimleri Dergisi, 7 (1), 111-130.

Aslan, Y. (2008). Savaş Hukukunun Temel Prensipleri, TBB Dergisi, (79), 235274.

Batır, K. (2011). Soğuk Savaş Sonrası Dönemde Amerikan Müdahaleciliği ve Uluslararası Hukuk, Yönetim Bilimleri Dergisi (Journal of Administrative Sciences), 9 (1), 115-134.

Bethlehem, D. (2012). Principles Relevant to the Scope of a state's Right of Self Defense Against an Immenent or Acyual Armed Attack By Non State Actors, The American Journal of International Law, Notes and Comments, 106:000, 1-8.

Cengiz, S. (2011). Avrupa Insan Hakları Mahkemesi Kararları Işs̆ğında Yaşam Hakkl, TBB Dergisi, (93), 383-404.

Dönmez, S. (2017). Kuvvet Kullanma Kapsamında Ön Alıcı ve Önleyici Saldırı Kavramları, Balkan ve Yakın Doğu Sosyal Bilimler Dergisi (Balkan and Near Eastern Journal of Social Sciences), 3 (3), 8-15.

Ergül, E. (2014). Özgürlük ve Güvenlik Dengesi Bağlamında Uluslararası Terörle Mücadele Stratejileri, EÜHFD, 18 (1-2), 63-98.

Pejic, J. (2015). Extraterritorial targeting by means of armed drones: Some legal implications, International Review of the Red Cross, 10.1017/S181 $6383114000447,1-40$.

Sathyamoorthy, D. (2015). A Review of Security Threats of Unmanned Aerial Vehicles and Mitigation Steps, The Journal of Defence and Security, (6).

Sevük, H. Y. (2012). Kolluk Görevlilerinin Silah Kullanma Yetkisi ve Yaşam Hakkl, Yeditepe Üniversitesi Hukuk Fakültesi Dergisi, 2 (2), 239-286.

Vogel, R. J. (2011). Drone Warfare and The Law of Armed Conflict, Drone Warfare and the Law of Armed Conflict, Denver Journal of International Law and Policy, 39 (1), 101-139. 


\section{Belgeler/Raporlar}

Council of Europe (2010). Avrupa İnsan Hakları Sözleşmesi. Council of Europe Publishing.

Davis, L. E., McNerney M. J., Chow J., Hamilton T., Harting S. \& Byman D. (2014). Armed and Dangerous? UAVs and U.S. Security, The RAND Corporation, USA.

Holloway, A. MP, Gupta A., Molyneux C. (2018). The UK's Use of Armed Drones: Working with Partners. All Party Parliamentary Group on Drones Inquiry Report, London.

Homeland Security (2017). Unmanned Aircraft Systems Addressing Critical Infrastructure Security Challenges, https://www.dhs.gov/sites/default/files/ publications/uas-ci-challenges-fact-sheet-508.pdf (erişim tarihi: 25.01. 2019).

International Court of Justice (2005). Armed Activities on the Territory of the Congo (Democratic Republic of the Congo v. Uganda), Judgment, I.C.J. Reports.

International Human Rights (IHR) and Conflict Resolution Clinic (CRC) (Stanford Law School) \& Global Justice Clinic (NYU School of Law) (2012). Living Under Drones: Death, Injury, and Trauma to Civilians from US Drone Practices Pakistan.

Melzer, N. (2009). Interpretive guidance on the notion of direct participation in hostilities under international humanitarian law. International Committee of the Red Cross (https://bit.ly/1WjvRb3).

Ökten, T. (2015). Uluslararası İnsancll Hukuk ve PKK Örneği, https://www. academia.edu/34367728/Uluslararas1_İnsanc11_Hukuk_ve_PKK_Örneği (erişim tarihi: 25.01.2019).

Schaus, J. \& Johnson, K. (2018). Unmanned Aerial Systems' Influences on Conflict Escalation Dynamics, CSIS Briefs, https://csis-prod.s3.amazonaws.com /s3fspublic/publication/180808_SchausJohnson_UnmannedAerialSystems_ UPDATE_0.pdf?ANfx9oj8wvgykmZ8QzlfJvgAfhGvtC1I (erişim tarihi 18.01.2019).

Quintana, E. (2008). The Ethics and Legal Implications of Military Unmanned Vehicles, The British Computer Society, Royal United Sevices Institute for Defence and Security Studies, Occasional Paper. 
Silahlı İnsansız Hava Araçlarının Uluslararası Alanda ve İç Güvenlikte

Sevk ve İdaresine İlişkin Hukuki Saptamalar

UK MoD (2017). Joint Doctrine Publication 0-30.2 Unmanned Aircraft Systems, The Development, Concepts and Doctrine Center, Ministery of Defence, Wiltshire, UK.

UN (2013). Report of the Special Rapporteur on the Promotion and Protection of Human Rights and Fundamental Freedoms While Countering Terrorism, A/68/389, 18 September 2013, https://unispal.un.org/DPA/DPR/ unispal.nsf/0/2DAADAFC 4682762585257C0B00609364.

US The White House (2002). The National Security Strategy of the United States of America, Washington DC, USA.

US DoD (2013). Unmanned System Integrated Roadmap FY 2013-2038, Washington DC, USA.

Woodhams, G. \& Borrie, J. (2018). Armed UAVs in Conflict Escalation and InterState Crisis, The United Nations Institute for Disarmament Research (UNIDIR), Geneva, Switzerland.

Yamaner, M.B., Öktem, E., Kurtdarcan, B., Uzun, M.C. (2008). 12 Ağustos 1949

Tarihli Cenevre Sözleşmeleri ve Protokolleri, Galatasaray Üniversitesi Hukuk Fakültesi Yayınları Nu:42, İstanbul.

\section{İnternet Kaynakları}

Alderton, M. (2018). To the Rescue! Why Drones in Police Work Are the Future of Crime Fighting, Apr 13 2018, https://www.autodesk.com/redshift/dronesin-police-work-future-crime-fighting/ (erişim tarihi: 28.01.2019).

BM Antlaşması (1945). Birleşmiş Milletler Antlaşması, https://www.tbmm.gov.tr/ komisyon/insanhaklari/pdf01/3-30.pdf (erişim tarihi: 28.01.2019).

European Court of Human Rights (1995), Case of Mccann and Others v. The United Kingdom, https://hudoc.echr.coe.int/eng\#\{"itemid":["001-57943"]\} (erişim tarihi: 24.05.2019).

Margaritoff, M. (2017). Drones in Law Enforcement: How, Where and When They're Used, October 13, 2017, http://www.thedrive.com/aerial/15092/ drones-in-law-enforcement-how-where-and-when-theyre-used (erişim tarihi: 28.01. 2019). 
Tucker, Patrick (2017). Look for Military Drones to Begin Replacing Police Helicopters by 2025, August 28, 2017, https://www.defenseone.com/ technology/2017/08/look-military-drones-replace-police-helicopters2025/140588/ (erişim tarihi: 28.01.2019).

Pilkington, E. (2014). 'We see ourselves as the vanguard': The Police Force Using Drones to Fight Crime, 1 Oct 2014, https://www.theguardian.com/world/ 2014/oct/01/drones-police-force-crime-uavs-north-dakota (erişim tarihi: 28.01.2019)

Stanley, J. (2017). Police Chiefs Issue Recommendations on Drones; A Look At How They Measure Up, August 17, 2012, https://www.aclu.org/blog/ privacy-technology/surveillance-technologies/police-chiefs-issue-recom mendations-drones-look?redirect=blog/technology-and-liberty/policechiefs-issue-recommendations-drones-look-how-they-measure (erişim tarihi: 28.01.2019). 